\title{
An Investigation on Coffee Thread Blight Caused by Corticium koleroga (Cke) Hoehnel and Its Associated Factors in Southwest Ethiopia
}

\author{
Nagassa Dechassa ${ }^{1, ~ *}$, Alemayehu Chala ${ }^{2}$, Kifle Belachew ${ }^{1}$, Elfinesh Shikur ${ }^{2}$ \\ ${ }^{1}$ Ethiopian Institute of Agricultural Research, Jimma Agricultural Research Centre, Jimma, Ethiopia \\ ${ }^{2}$ School of Plant and Horticultural Sciences, College of Agriculture, Hawassa University, Hawassa, Ethiopia
}

Email address:

nagookooti@gmail.com (N. Dechassa)

${ }^{*}$ Corresponding author

\section{To cite this article:}

Nagassa Dechassa, Alemayehu Chala, Kifle Belachew, Elfinesh Shikur. An Investigation on Coffee Thread Blight Caused by Corticium koleroga (Cke) Hoehnel and Its Associated Factors in Southwest Ethiopia. Journal of Drug Design and Medicinal Chemistry. Vol. 6, No. 3, 2020, pp. 22-29. doi: 10.11648/j.jddmc.20200603.11

Received: October 6, 2020; Accepted: October 20, 2020; Published: October 30, 2020

\begin{abstract}
Thread blight caused by Corticium koleroga is a devastating disease that causes severe damage to C. arabica in south-western Ethiopia. However, it is one of the least researched diseases in Ethiopia. Therefore, the current work was designed with the objectives to assess the incidence and severity of the disease and identifying major factors associated with the disease intensity in south-western Ethiopia. For this purpose, field surveys were conducted on 180 farmers' fields in 12 districts of major coffee growing areas in south-western Ethiopia during 2017 cropping season. The average thread blight incidence varied from $0 \%$ to $46 \%$ while mean disease severity ranged from $0 \%$ to $44 \%$. The thread blight disease incidence and severity were higher at areas representing highland and midland altitudes compared with lowland altitudes. Thread blight severity was positively and strongly associated with rainfall $(\mathrm{r}=0.75)$ and relative humidity $(\mathrm{r}=0.85)$, but the disease severity was negatively and strongly associated with mean temperature $(\mathrm{r}=-0.79)$ and shade level $(\mathrm{r}=-0.50)$, while it was positively and intermediately correlated to altitude $(\mathrm{r}=0.44)$ and coffee production systems $(\mathrm{r}=0.36)$. The present study revealed the importance of coffee thread blight in south-western Ethiopia and identified factors associated with the disease intensity. Future research should be directed towards surveying more agro-ecologies to have a complete picture on the importance of thread blight disease across the country and to recommend disease management strategies.
\end{abstract}

Keywords: Disease Intensity, Incidence, Koleroga, Severity, Southwest Ethiopia

\section{Introduction}

Coffea arabica $\mathrm{L}$. is the most important agricultural crop in Ethiopia, contributing around one quarter of its total export earnings [1]. Coffee farming provides a livelihood income for around 15 million Ethiopians (16\% of the population), based on four million small-holder farmers [1-3]. Coffee is one of the highly preferred international beverages and also one of the most important trade commodities in the world next to petroleum [4]. In Ethiopia, Arabica coffee grows under very diverse agro-ecosystems and wider ranges of altitudes, temperature, rainfall, humidity and soil types [5].

The main coffee growing areas in Ethiopia are found within the southwest, southeast and eastern parts of the country (Oromia and Southern Nations, Nationalities and Peoples' Regions), with modest and minor production in the north (Amhara and Benishangul Gumuz Regions, respectively). The plant is grows under different types of production systems i.e., forest, semi forest, garden and plantation coffee production systems [6,7].

Even though $C$. arabica is the key cash crop and top foundation of the Ethiopian economy; numerous production constraints have been affecting the production and productivity of coffee. Abiotic and biotic factors are the major constraints of coffee production in the country among which are fungal diseases attacking fruits, leaves, stems and roots, and reduce the yield and marketability. Coffee thread blight (CTB) caused by Corticium koleroga (Cke) Hoehnel 
on Ethiopian coffee was known for more than 40 years and considered as minor coffee disease, but it is increasingly becoming an important disease and has been observed in wide coffee growing regions of Ethiopia as an epidemic disease in 2014 [8].

Previously CTB disease intensity was assessed on plantation coffee production systems in limited coffee agro ecosystems, but currently the disease has been observed in all coffee production systems across different regions of Ethiopia. Although the disease is becoming increasingly very important in Ethiopia, there is little information about quantitative data that reflects the extent of its distribution in garden, forest and semi-forest coffee production systems of different coffee growing areas across the country.

The CTB disease was less recognized since its diagnosis in the late 1970s to late 2000s, but as presented earlier in the reports and articles, it then became prevalent and economically important [JARC, 2012 unpublished; JARC, 2014 unpublished; 8]. Although the emergence and increasing rate of CTB disease is associated with many factors, but the information about the factors associated with the disease intensity has not yet been clearly identified in Ethiopia. Therefore, the present study was initiated with the following objectives:

1) To assess the incidence and severity of coffee thread blight in South-western Ethiopia

2) To identify the major factors associated with thread blight epidemics.

\section{Materials and Methods}

\subsection{Study Areas and Sampling System}

Field surveys were carried out during the 2017 rainy season in different coffee growing districts of Ilubabor and Jimma zones in Oromia, and Benchimaji and Sheka zones in South Nation Nationality and Peoples Regional State (SNNPRS). Mettu, Alle and Yayu from Ilubabor; Gera, Gomma and Shebesombo from Jimma; Debubbench, Shako and Gurafarda from Benchimaji; and Yaki, Andaracha and Masha districts from Sheka zones (Figure 1) were selected in order to assess the intensity of thread blight disease. The selected districts are located at different altitudes ranging between 985 and 2010 meters above sea level (m.a.s.l.). From each of the mentioned districts, three coffee growing farmers' associations were randomly selected.

Also from each of the selected farmers' associations, five coffee fields were randomly selected at distances of 10-15 $\mathrm{km}$ along the main and accessible rural roads. From each coffee farm, based on the size of the farm, 30-50 trees at 6-8 $\mathrm{m}$ distances were used for disease assessment. The age of coffee trees varied from 3 to 30 years. During the survey, small scale and large scale farms were considered.

\subsection{Assessment of Coffee Thread Blight}

Disease assessment was done by visual estimation method per individual sample of coffee tree. In visual estimation method, 30-50 coffee trees were randomly selected in diagonal path from each farm and the number of diseased twigs, leaves and berries were recorded separately and percent of disease incidence and severity were calculated per the mean of plant parts.

Disease Incidence (DI):- The percent of disease incidence was computed for twigs, leaves and berries separately and converted to per plant basis by taking the mean of percent disease incidence of the three plant parts. Percent of disease incidence was computed according to the following equation.

$$
\text { DI }=\frac{\text { Number of infected plant parts (twigs or leaves or berries) }}{\text { Total number of plant parts (twigs or leaves or berries)assessed }} * 100
$$

Disease Severity (DS):- The data regarding the severity of CTB disease was recorded with the slight modification in scale (1-9) devised by [9] whereas $1=$ no disease, $2=$ disease affecting 1 to $4 \%$ of plant part surface, $3=5$ to $9 \%, 4=10$ to $19 \%, 5=20$ to $29 \%, 6=30$ to $44 \%, 7=45$ to $59 \%, 8=60$ to $75 \%$, and $9 \geq 75 \%$ of plant part surface affected. Disease severity on tree leaves, berries and twigs was also estimated based on percent surface covered by lesions of the disease over total area observed. The percent of disease severity was computed for twigs, leaves and berries separately and converted to per plant basis by taking the mean of disease severity percentage of the three plant parts. This parameter was computed according to the following formula.

$$
\text { Disease Severity }(\%)=\frac{\text { Plant part covered by lesions or rot }}{\text { Total plant part assessed }} * 100
$$

\subsection{Identification of the Factors Associated with CTB}

Data on shade level, shade type, altitude, variety, coffee yield pattern, production system and meteorological factors (i.e. mean temperature, annual cumulative rainfall and relative humidity) were collected to determine their influence on CTB development.

\subsubsection{Shade Types}

Data on shade type were collected at three levels, where coffee farms shaded with more than one tree species were recorded as mixed tree species, while those with only one tree species were recorded as mono tree species and unshaded farms in open sun were recorded as no-shade [9].

\subsubsection{Shade Level}

Nature of shade at each farm was assessed by visual estimation using a rating scale; No shade (open) $=100 \%$ light penetration, thin (low) shade $=99 \%$ to $70 \%$, Medium shade $=69 \%$ to $40 \%$ and Thick (high) shade $=39 \%$ to $20 \%$ [10].

\subsubsection{Altitude}

Altitude in meters above sea level (m.a.s.l.) was recorded, using Geographic Positioning System (GPS) at a central point for each farm surveyed.

\subsubsection{Meteorological Data}

Such as annual cumulative rainfall, mean temperature and relative humidity of the surveyed areas were obtained from 
the nearest meteorological stations (Table 1). The monthly weather data (rainfall, temperature and relative humidity) of the surveyed districts were summarized into yearly time scale. The missing daily data were filled by multiple imputation method using XLSTAT statistical software [10].

\subsubsection{Varieties}

The kind of planted coffee variety was asked from the growers and the data were recorded.

\subsubsection{Coffee Yield Pattern}

Yield bearing condition of the plant for example biennially or annually was asked from the growers and the data were recorded.

Besides, age of coffee grown in each farm, chemicals and fertilizers used over the past years were recorded during farmers' interview.

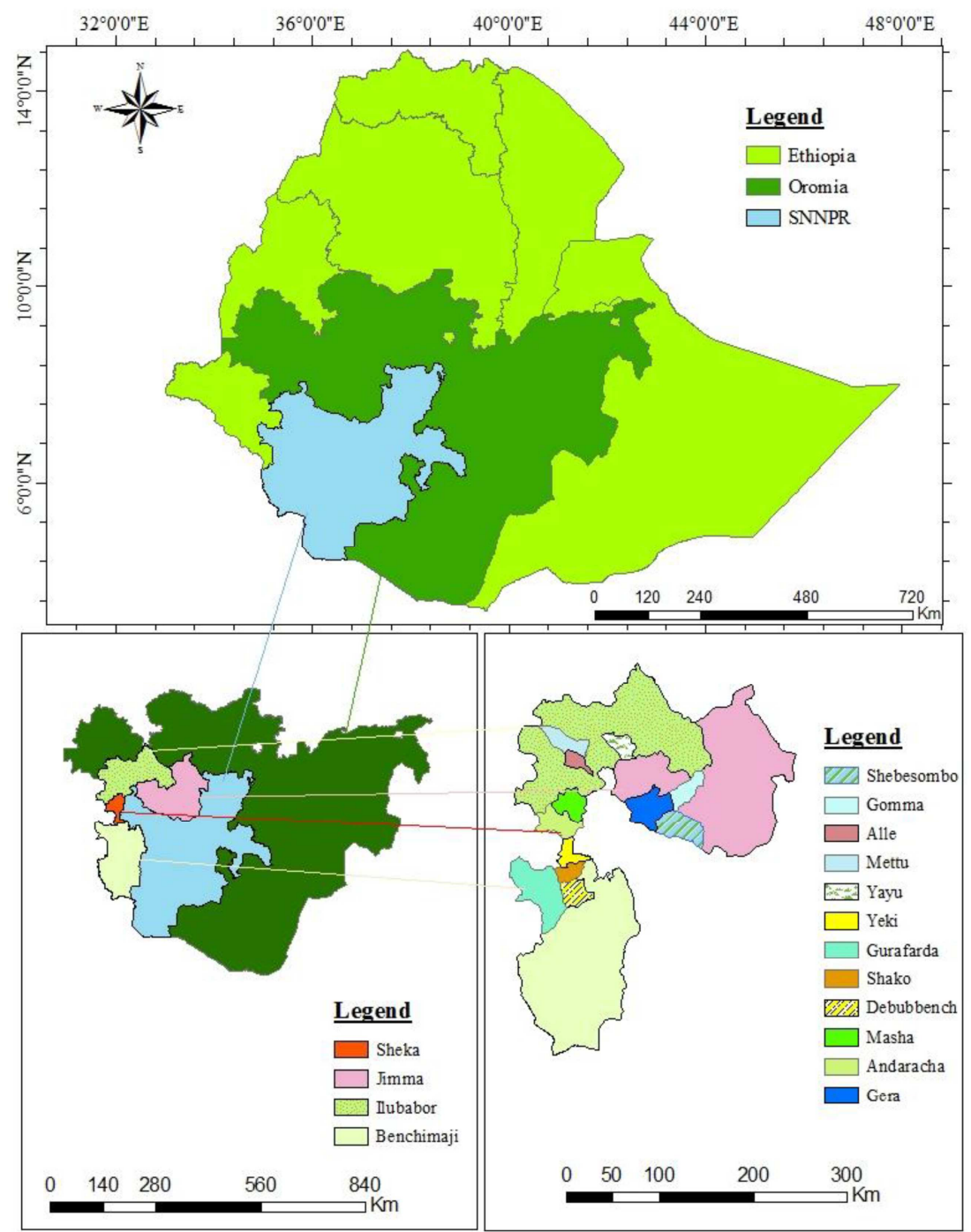

Figure 1. Map of Ethiopia showing regions, zones and districts of Southwest Ethiopia included in the survey program.

Table 1. Geographical description and average of 11 years weather data of districts included in the survey program.

\begin{tabular}{|c|c|c|c|c|c|}
\hline Study sites & Altitude (m.a.s.l) & Location & Annual rainfall (ml) & Mean temperature $\left({ }^{\circ} \mathrm{C}\right)$ (Minimum-maximum) & Relative Humidity (\%) \\
\hline Debubbench & 1192 & $6^{\circ} 95^{\prime} \mathrm{N} 36^{\circ} 00^{\prime} \mathrm{E}$ & 1878.12 & 27.87 & 70.84 \\
\hline Shako & 1150 & $7^{\circ} 04^{\prime} \mathrm{N} 35^{\circ} 25^{\prime} \mathrm{E}$ & 1535.40 & 31.40 & 71.03 \\
\hline Gurafarda & 1259 & $6^{\circ} 52^{\prime} \mathrm{N} 35^{\circ} 18^{\prime} \mathrm{E}$ & 1568.88 & 28.28 & 70.28 \\
\hline Masha & 2282 & $7^{\circ} 75^{\prime} \mathrm{N} 35^{\circ} 47^{\prime} \mathrm{E}$ & 2032.12 & 22.81 & 75.70 \\
\hline Yaki & 1285 & $7^{\circ} 20^{\prime} \mathrm{N} 35^{\circ} 33^{\prime} \mathrm{E}$ & 1491.56 & 29.79 & 69.45 \\
\hline Andarach & 1816 & $7^{\circ} 28^{\prime} \mathrm{N} 35^{\circ} 23^{\prime} \mathrm{E}$ & 1820.21 & 24.00 & 74.25 \\
\hline Mettu & 1550 & $8^{\circ} 30^{\prime} \mathrm{N} 36^{\circ} 00^{\prime} \mathrm{E}$ & 1948.56 & 27.00 & 74.50 \\
\hline Alle & 2033 & $8^{\circ} 13^{\prime} \mathrm{N} 35^{\circ} 53^{\prime} \mathrm{E}$ & 1811.49 & 24.41 & 75.40 \\
\hline Gera & 1940 & $7^{\circ} 70^{\prime} \mathrm{N} 36^{\circ} 00^{\prime} \mathrm{E}$ & 1645.13 & 24.35 & 75.03 \\
\hline Gomma & 1666 & $7^{\circ} 85^{\prime} \mathrm{N} 36^{\circ} 60^{\prime} \mathrm{E}$ & 1521.01 & 28.65 & 72.73 \\
\hline Shebesombo & 1813 & $7^{\circ} 50^{\prime} \mathrm{N} 36^{\circ} 52^{\prime} \mathrm{E}$ & 1558.72 & 14.16 & 70.21 \\
\hline
\end{tabular}




\subsection{Data Analysis}

Data on disease incidence and severity were analyzed using descriptive statistics. The associations of disease incidence and severity with independent variables such as altitude, production systems, shade level, yield pattern, coffee varieties and meteorological data were analyzed using Pearson correlation and regression using SPSS 20.0 software package [12].
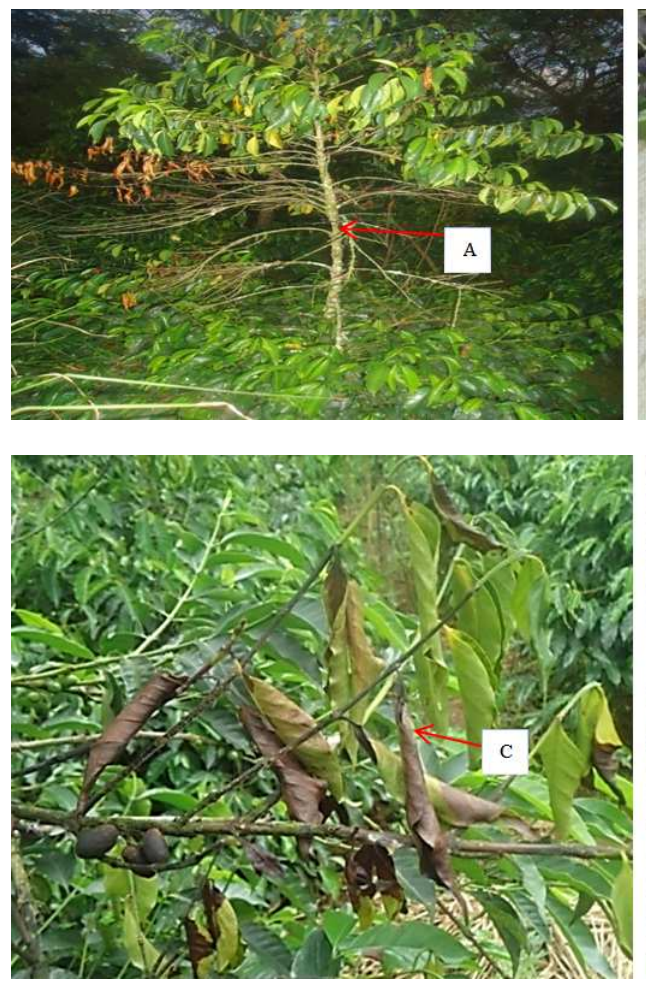

Figure 2. Thread blight disease on Coffea arabica was seen as thread-like white to ashen strand on: a) stem b) branch, c) leaf, and d) berry observed at Metu.

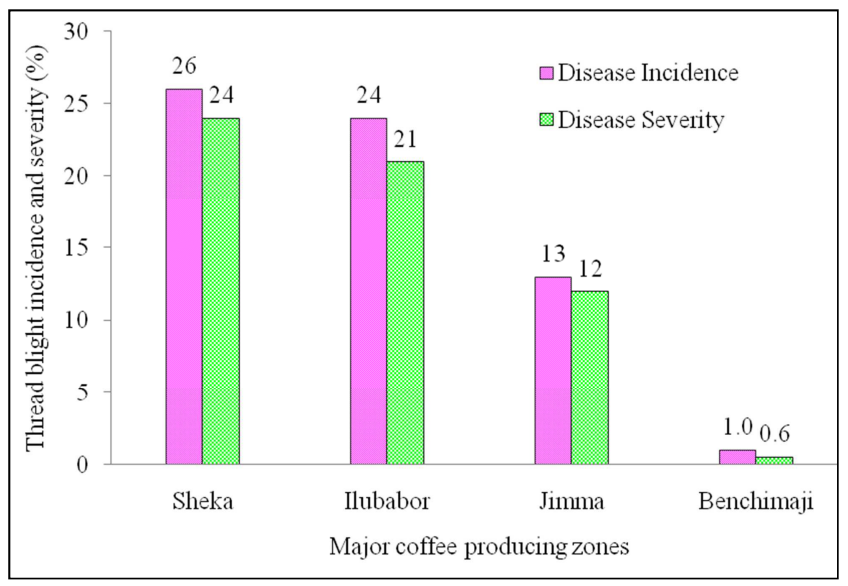

Figure 3. Incidence and severity of thread blight in four zones of Southwest Ethiopia in 2017.

There was a significant difference in disease intensity across the surveyed administrative zones. At administrative zone level, the highest mean disease incidence (26.47\%) and severity $(24.98 \%)$ were recorded at Sheka zone, which

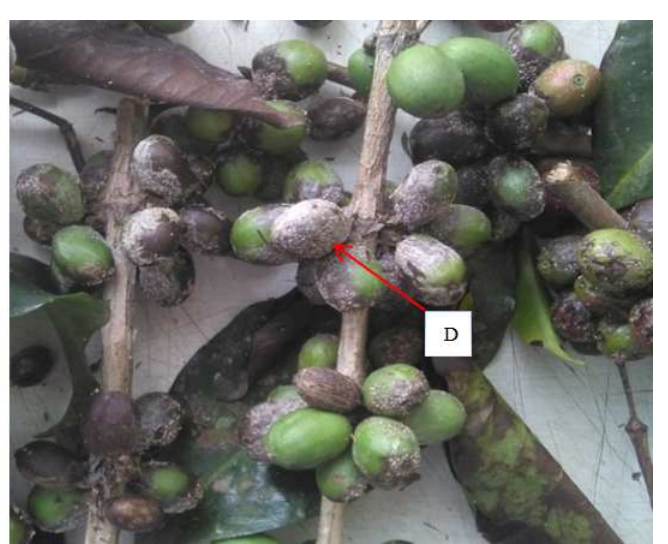

\section{Results and Discussions}

\subsection{Coffee Thread Blight Intensity Across South Western Parts of Ethiopia}

Thread blight of coffee was prevalent in southwest Ethiopia as evidenced from the typical disease symptoms on various plant parts (Figure 2).

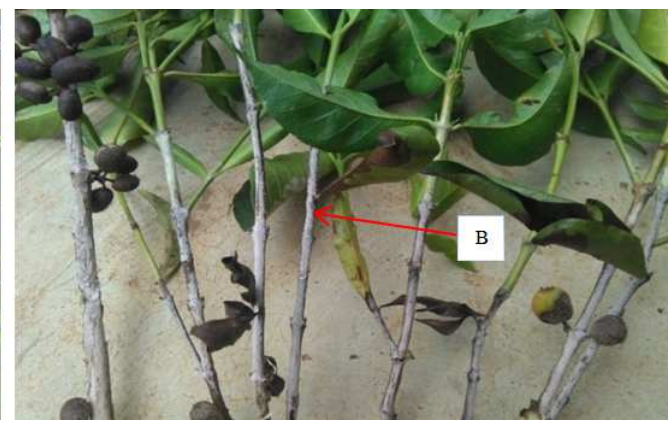

represents highland altitude while the lowest mean disease incidence $(0.90 \%)$ and severity $(0.56 \%)$ were recorded at Benchimaji zone, which represents lowlands (Figure 3). Jimma and Illubabor representing midland altitudes had intermediate disease level.

Thread blight intensity among the surveyed administrative districts of the Southwest part of Ethiopia was also highly variable. At district level, the disease severity ranged between 0 to $44.04 \%$. The highest mean CTB disease incidence $(45.86 \%)$ and severity $(44.04 \%)$ were recorded in Masha district followed by Mettu, Andaracha, Alle, Gera and Gomma in that order. On the other hand, the disease was absent $(0 \%$ incidence) in Debubbench, Yaki and Gurafarda districts (Table 2).

Thread blight disease on Coffea arabica in Ethiopia was known for more than 40 years and considered as minor coffee disease. It sporadically occurred every five to six years between June and September as minor and locally important before 2012 but it gradually became serious and widely observed at midland and highland coffee growing areas of Ethiopia around Gera, Mettu and Limmu coffee plantations and appeared as an epidemic in 2014 [8]. 
Table 2. Incidence and severity of thread blight at districts of southwest Ethiopia in 2017.

\begin{tabular}{llllll}
\hline Zone & District & No. of farms surveyed & Altitude (m.a.s.l.) & Incidence (\%) & Severity (\%) \\
\hline Sheka & Masha & 15 & $1550-2010$ & 45.86 & 44.04 \\
Ilubabor & Mettu & 15 & $1550-1974$ & 42.65 & 40.04 \\
Sheka & Andaracha & 15 & $1220-1830$ & 27.53 & 22.26 \\
Ilubabor & Alle & 15 & $1350-1838$ & 25.55 & 22.56 \\
Jimma & Gera & 15 & $1616-1989$ & 21.05 & 19.04 \\
Jimma & Gomma & 15 & $1550-1675$ & 19.23 & 12.33 \\
Ilubabor & Yayu & 15 & $1420-1969$ & 13.85 & 2.58 \\
Benchimaji & Shako & 15 & $1072-1724$ & 2.70 & 1.14 \\
Jimma & Shebesombo & 15 & $1550-1795$ & 1.28 & 0 \\
Benchimaji & Gurafarda & 15 & $1070-1414$ & 0 & 0 \\
Benchimaji & Debubbench & 15 & $985-1293$ & 0 & 0 \\
Sheka & Yaki & 15 & $1189-1260$ & 0 & \\
\hline
\end{tabular}

The first recorded thread blight disease outbreak on $C$. arabica occurred in 2008 at Limmu coffee plantation farm of Gumer with mean disease incidence and severity of $49.2 \%$ and $9.8 \%$, respectively [8]. Another outbreak occurred at Bebeka in 2012 (JARC, 2012 unpublished). CTB was also reported from AgriCeft coffee plantation of Duyina farm in Masha district of Sheka zone with mean disease incidence and severity of $50.4 \%$ and $30.9 \%$, respectively (JARC, 2012 unpublished). In the same year, the disease outbreak was further noted in coffee growing farms of Limmu Sintu and Gumer with mean incidence and severity of 66.5 and $32.3 \%$, respectively (JARC, 2012 unpublished). CTB outbreaks were recorded for the third time at major coffee growing areas of south-western (Mettu and Gera), western (Mugi) and southern (Awada) parts of Ethiopia in 2014 with mean incidence and severity of 58.4 and $32.6 \%$, respectively, resulting in considerable damages [8]. Since then the disease is recurring every year and spreading to the neighbouring zones of coffee producing areas of Ethiopia.

The greater or lesser severity of the disease is linked to several factors related to the environment, pathogen, host and human activities. Over-exposure of coffee farms to sunlight, over-production with deficient plant nutrition, difficult adaptation of certain genotypes may also increase the intensity of the disease. Hereunder, the effects of factors associated with the disease are discussed.

\subsection{Factors Affecting Thread Blight Disease}

\subsubsection{Shade Levels}

There was highly significant $(p<0.01)$ and negative correlation between shade level on one hand and CTB disease incidence and severity $(r=-0.51)$ on the other (Table 3 ). The disease became more intense as shade level decreases. Accordingly, the highest mean disease incidence $(64.08 \%)$ and severity $(57.28 \%)$ were recorded under full sun light (open) growing conditions. Low, medium and high shade levels had CTB incidence and severity of 37.58 and $32.63 \%, 6.73$ and $6.44 \%$, and 4.65 and $4.19 \%$, respectively. This pattern could have resulted from the following reasons: a) shade tree prevents fruit loads (optimizes fruits to leaves ratio), b) it modifies microclimate conditions c) it serves as habitat for a large number of species which are directly involved in pest and disease bio-control, d) it limits the splash dispersal of propagules which serve as inoculum.

Table 3. Pearson correlation coefficients between disease intensity and associated factors

\begin{tabular}{|c|c|c|c|c|c|c|c|}
\hline & DI & DS & SL & ST & Alt & PS & $\mathbf{Y P}$ \\
\hline DI & & & & & & & \\
\hline DS & $0.99^{* *}$ & & & & & & \\
\hline SL & $-0.51^{* *}$ & $-0.51^{* *}$ & & & & & \\
\hline ST & $-0.49^{* *}$ & $-0.48^{* *}$ & $0.66^{* *}$ & & & & \\
\hline Alt & $0.43^{* *}$ & $0.44^{* *}$ & $-0.21^{* *}$ & $-0.23^{* *}$ & & & \\
\hline PS & $0.39^{*}$ & $0.36^{*}$ & $0.05^{\mathrm{ns}}$ & $-0.05^{\mathrm{ns}}$ & -0.12 & & \\
\hline YP & $-0.45^{* *}$ & $-0.43^{* *}$ & $-0.03^{\mathrm{ns}}$ & $0.04^{\mathrm{ns}}$ & $0.09^{\text {ns }}$ & $-0.78^{* *}$ & \\
\hline Variety & $-0.03^{\mathrm{ns}}$ & $-0.03^{\text {ns }}$ & $-0.24^{* *}$ & $-0.13^{\mathrm{ns}}$ & $-0.16^{*}$ & $-0.01^{\mathrm{ns}}$ & $-0.003^{\mathrm{ns}}$ \\
\hline
\end{tabular}

$\mathrm{DI}=$ Disease Incidence, DS=Disease severity, $\mathrm{SL}=$ Shade Level, $\mathrm{ST}=$ Shade Type, Alt=Altitude, $\mathrm{PS}=\mathrm{Production}$ system, YP=Yield Pattern, *=correlation is significant at $\mathrm{p} \leq 0.05 * *=$ correlation is significant at $\mathrm{p}<0.01,{ }^{\mathrm{ns}}=$ correlation is insignificant at $\mathrm{p} \leq 0.05$.

The current results are in agreement with $[13,14]$, who suggested that medium and high shade levels help to prevent high fruit loads and optimizes sink (fruit) to source (leaf) ratio of the coffee plant, which in turn decreases leaf receptivity to the pathogen. Shade trees also provide multiple services in forest and semi-forest coffee production systems and can help to naturally reduce several coffee pests via different pathways (by modifying microclimate conditions)

\section{$[13,14]$.}

Forest and semi-forest coffee production systems have a higher level of biodiversity as compared to plantation and garden production systems under low shade level to full sunlight. Trees shade, which can be very diverse and abundant in certain rural agro-forestry systems, provides habitats for a large number of species which are directly involved in pest and disease bio-control [15]. It has been 
suggested by [16] that trees shade reduces coffee fungal diseases' incidence by intercepting rainfall and reducing the intensity of rain drop impacts on coffee trees, thereby limiting the splash dispersal of propagules. The service provided by shade in controlling coffee disease is associated with a disservice in reducing yield in the short term [17].

However $[18,8]$ indicated that shade is known to be conducive to $C$. koleroga and $C$. salmonicolor which contradicts with these research results. However, in the current study careful observations at Masha district (Yepho and Abelo peasant associations), Andaracha district (Duyina coffee farms) and Mettu district (Geyi and Ehudgeba peasant associations) revealed that most of the coffee plantation farms representing high CTB disease incidence and severity were cultivated under low shade to open sun, indicating open sun and low shade are conduciveness for the growth and development of CTB pathogen.

The coffee trees cultivated under medium to high strata of forest and agro-forestry trees, like in the case of Shako district (Berhane kontir forest, Shimmi peasant associations), Shebesombo district (Anjagembo and Sabakawala peasant associations) and Yayu district (Yayu forest) had nil to very low CTB disease incidence and severity, strongly confirming the role of shading in preventing/reducing the CTB disease. This is also supported by [19], which reported that some coffee fungal diseases like coffee blight (Phoma costarricencis) can be reduced by establishing windbreaks and shade trees because of the fact that trees intercept winds, particularly cold winds and protect coffee parts from mechanical injuries, which otherwise enable the pathogen to penetrate. [20] reported that tree shade creates microclimatic conditions that helped to reduce fruit load, which might have led to a shift in the period of coffee tree susceptibility in relation to high disease pressure. [16] also suggested that shade can affect and modify certain rainfall characteristics, which might influence pathogen dispersal.

\subsubsection{Shade Type}

In this study, there was highly significant difference $(p<0.01)$ and negative intermediate correlation between shade type and CTB disease incidence $(r=-0.49)$ and severity $(r=-0.48)$ (Table 3). The disease became more intense under no shade followed by mono-shade, whereas low disease incidence and severity were recorded under mixed shade types. Correspondingly higher average disease incidence $(41.56 \%)$ and severity (37.34\%) were recorded under unshaded farms followed by farms with single tree species (13.42\% and $12.58 \%)$ and the lowest (12.67\% and $11.77 \%)$ diseases incidence and severity, respectively, in farms with mixed tree species.

\subsubsection{Coffee Production Systems}

There was significant $(p<0.05)$ and positive intermediate correlation between coffee production systems and CTB disease incidence $(r=0.39)$ and severity $(r=0.36)$ (Table 3$)$. The disease became more intense in plantation followed by garden, semi forest and forest coffee production systems. The occurrence of CTB is higher in plantations and gardens with poor cultural practices, especially, when the normal rounds of pruning unnecessary twigs are not practiced and optimum shade is not provided. The probable reason for the variation in intensity of coffee thread blight disease among the different production systems could be the effect of human interference. The intensity of CTB in plantation and garden production systems was the highest of all, due to the fact that the coffee farms are slashed frequently for weed control and exposed to soil erosion where as low human interference in forest and semi-forest coffee production systems could attribute to the relatively reduced disease intensity.

Human beings have a considerable role in transmitting disease causing pathogens from diseased plant part to unaffected plant part or from diseased plant to unaffected plant or from affected farm to unaffected coffee farms. [21] noted frequent human interference hastened the spatial and temporal dispersal of fungal pathogens.

The other probable reason for the variation in intensity of coffee thread blight disease among the different production systems could be the effect of difference in shade levels and shade types across the different coffee production systems. In the plantation and garden coffee production systems, majority of the coffee trees are with low or without shade, which may attribute to high disease intensity. On the other hand, in forest and semi-forest coffee production systems, coffee trees are self-grown under spontaneously regenerating natural forest cover, where different species of trees provide shade to the coffee plants. According to [18], the effects of agro-forestry on invertebrate pests and diseases were dependent on crop type. In perennial crops (e.g. coffee, cocoa and plantain), agro-forestry was associated with lower pest abundances and less plant damage. All forest and most of semi-forest coffee production systems are often managed with shade trees, with non to minimal fertilization, but litter fall and decomposition play an important role in nitrogen recycling and maintenance of soil fertility [22].

\subsubsection{Coffee Yield Pattern and Variety}

There was highly significant $(p<0.01)$ and negative intermediate correlation between coffee yield pattern and CTB disease incidence $(r=-0.45)$ and severity $(r=-0.43)$ (Table 3). Higher mean disease incidence of $21.70 \%$ and severity of $19.87 \%$ were recorded in the annual than in the biennial coffee.

There was negative weak correlation between coffee varieties and CTB disease incidence $(r=-0.02)$ and severity $(r=-0.03)$ (Table 4). The disease became more intense (mean incidence of $17.47 \%$ and severity of $16.27 \%$ ) on local varieties than on improved varieties.

\subsubsection{Altitude}

Altitude is also one of the factors positively associated with CTB disease. There was a positive intermediate correlation between altitude and incidence $(\mathrm{r}=0.43)$ and severity $(\mathrm{r}=0.44)$ of CTB disease (Table 3$)$. The highest mean disease incidence $(28.09 \%)$ and severity $(25.70 \%)$ across altitude gradients were recorded at highland coffee producing areas, whereas percent of disease incidence and severity were 
very low at lowland areas with mean disease incidence of $4.04 \%$ and severity of $3.69 \%$. As in the cases of districts such as Masha, Mettu, Andaracha, Alle, Gera, Gomma and Yayu, which are located in medium to higher altitude $(>1500$ m.a.s.1), the percent of disease incidence and severity increased with increasing altitudes. This might be because of prolonged rainfall and storms accompanied by hail in the highland areas like Mettu and Masha.

\subsubsection{Meteorological Factors}

Thread blight incidence and severity had highly significant $(\mathrm{p}<0.01)$ correlations with cumulative rainfall $(\mathrm{r}=0.74$ and $\mathrm{r}=0.75$, respectively), relative humidity $(\mathrm{r}=0.86$ and $\mathrm{r}=0.85$, respectively) and mean temperature $(\mathrm{r}=-0.81$ and $\mathrm{r}=-0.79$, respectively) (Table 4).

Table 4. Pearson correlation coefficients between disease intensity and meteorological factors.

\begin{tabular}{lllll}
\hline & Incidence & Severity & Rainfall & Relative Humidity \\
\hline Incidence & & & & \\
Severity & $0.99^{* *}$ & & & \\
Rainfall & $0.74^{* *}$ & $0.75^{* *}$ & $0.67^{*}$ & $-0.86^{* *}$ \\
Relative Humidity & $0.86^{* *}$ & $0.85^{* *}$ & $-0.62^{*}$ & $-0.79^{* *}$ \\
Temperature & $-0.81^{* *}$ & & \\
\hline
\end{tabular}

$*=$ Significant at $\mathrm{p}<0.05, * *=$ Significant at $\mathrm{p}<0.01$.

The result of this research indicated that the decreased level of rainfall and relative humidity may lead to decreased incidence and severity of thread blight disease on C. arabica. Whereas the periods of high and prolonged rainfall and high relative humidity, which result in prolonged periods of plant parts wetness, are the most important meteorological factors influencing the occurrence and further development of CTB disease in the field.

Environmental changes can also indirectly influence the biology of a pathogen by changing the plant architecture, thereby altering the microenvironment. For example, canopy density and structure can affect the temperature, moisture and availability of ultraviolet light at an infection site. Increased plant and leaf densities tend to increase leaf wetness, thus promoting the development of pathogens that prefer humid conditions [23].

\section{Conclusions and Recommendations}

In conclusion thread blight disease caused by $C$. koleroga is becoming an important disease in coffee producing areas of south-western Ethiopia. The disease intensity varied across the investigated regions, zones and districts. The highest mean disease incidence (46\%) and severity (44\%) was recorded at Masha district followed by Mettu with mean DI $(42 \%)$, DS $(40 \%)$ representing highland and midland altitudes, respectively. On the other hand, the disease intensity was absent in Debubbench, Yaki and Gurafarda districts representing lowland altitude.

Cumulative rainfall, relative humidity, mean temperature, altitude, coffee production system, shade level and shade types have considerable impact on the intensity of thread blight. Increased level of rainfall and relative humidity were associated with an increased risk of CTB disease development on $C$. arabica. Besides, disease intensity was the highest at midland and highland altitudes, plantation coffee production systems, open shade level and local coffee varieties.

Since the present status of thread blight is remarkably on increasing trend, it is recommended to:-1) Carry out successive surveys of thread blight disease in all coffee growing areas across the country to have a complete picture on the importance of the disease across coffee agroecosystems. 2) Further investigation on the impacts of weather variables and other factors on thread blight intensity under different agro-ecological conditions in multi-location and multiyear trials to come up with conclusive results. 3) Study on safe, effective and environmentally friendly disease management options such as cultural practices, biological control and integrated disease management.

\section{Conflict of Interests}

The authors declare that they have no competing interests.

\section{Acknowledgements}

The authors would like to thank Ethiopian Institute of Agricultural Research (EIAR) for the financial support. Special thanks also go to Jimma Agricultural Research Centre (JARC) and Mettu Agricultural Research sub-Centre (MARsC) for facilitating logistical support.

The authors also acknowledge the colleagues at JARC and MARsC for their helpful suggestions and technical support during the study.

\section{References}

[1] Minten B, Tamru S, Kuma T, Nyarko Y (2014). Structure and Performance of Ethiopia's Coffee Export Sector. Working Paper 66 (EDRI/IFPRI, 2014).

[2] ICO (International Coffee Organization) (2016). Historical Data on the Global Coffee Trade. Available on http://www.ico.org/new storical.asp (2016). Accessed on June, 2018.

[3] Abu T (2015). Ethiopian Coffee Annual: GAIN Report Number: ET1514. Addis Ababa, Ethiopia.

[4] ICO (International Coffee Organization) (2012). Monthly coffee market report. Available on www.ico.org/documents/cmr-0712-e. Accessed on September, 2018. 
[5] Mesfin A, Bayetta B (1987). Genotype x Environment Interaction in Coffea arabica. Proceedings of Fourth International Scientific Colloquium on Coffee, pp. 476-482.

[6] Melkam A (2015). Coffee Seed Production and Supply at Research Centre in Ethiopia. J. Biol. Med. Scien. 2: 82-88.

[7] Moat J, Williams J, Baena S, Wilkinson T, Gole W, Chala K, Demissew S, Davis P (2017). Resilience Potential of the Ethiopian Coffee Sector under Climate Change. Nature plants 3: $17-81$.

[8] Belachew K, Teferi D, Hagos L (2015). Coffee Thread Blight (Corticium koleroga): a Coming Threat for Ethiopian Coffee Production. J. Plant Pathol. Microb. 6: 303-308.

[9] Zadoks C, Schein D (1979). Epidemiology and Plant Disease Management. Oxford University Press, Oxford, UK, 427p.

[10] Matovu J, Kangire A, Phiri A, Hakiza J, Kagezi H, Musoli C (2013). Ecological Factors Influencing Intensity of Coffee Leaf Rust and Coffee Berry Disease in Major Arabica Coffee Growing areas of Uganda. Uganda J. Agric. Sci. 14: 87-100.

[11] Schneider T (2001). Analysis of incomplete climate data: estimation of mean values and covariance matrices and imputation of missing values. Climate 14: 853-871.

[12] Green B, Salkind J (2016). Using SPSS for Windows and Macintosh, Books Carte. Pearson.

[13] Staver C, Guharay F, Monterroso D, Muschler G (2001). Designing pest-suppressive multi strata perennial crop systems: shade-grown coffee in Central America. Agrofor. Sys. 53: 151-170.

[14] Ratnadass A, Fernandes P, Avelino J, Habib R (2011). Plant Species Diversity for Sustainable Management of Crop Pests and Diseases. Agro ecosystems: A Review. Agron. Sustain. Dev. 32: 273-303.

[15] Soto-Pinto L, Romero-Alvarado Y, Caballero-Nieto J, Warnholtz S (2001). Woody plant diversity and structure of shade grown coffee plantations in Northern Chiapas, Mexico. Rev. De Bio. Trop. 49: 977-987.

[16] Mouen-Bedimo A, Njiayouom I, Bieysse D, Nkeng N, Cilas C, Notteghem L (2008). Effect of Shade on Coffea arabica Berry Disease Development: Toward an Agro forestry System to Reduce Disease Impact. Phytopathology 98: 320-325.

[17] López-Bravo, Virginio F, Avelino J (2012). Shade is Conducive to Coffee Rust as Compared to Full Sun Exposure Under Standardized Fruit Load Conditions in A Sub-Optimal Zone for Coffee in Costa Rica. In: The $24^{\text {th }}$ International Conference on Coffee Science, pp. 21-29.

[18] Schroth G, Krauss U, Gasparotto L, Aguilar D, Vohland K (2000). Pests and diseases in agro forestry systems of the humid tropics. Agrofor. Syst. 50: 199-241.

[19] Muller A, Berry D, Avelino J, Bieysse D (2004). Coffee Diseases. Wintgens, N. (Ed.), Coffee: Growing, Processing, Sustainable Production: A Guidebook for Growers, Processors, Traders, and Researchers, pp. 491-545.

[20] Vaast P, Bertrand B, Perriot J, Guyot B, Genard M (2006). Fruit thinning and shade improve bean characteristics and beverage quality of coffee (Coffea arabica L.) under optimal conditions. J. Sci. Food Agric. 86: 197-204.

[21] Bieysse D, Cilas C, Mouen J, Musoli P, Avelino J (2008). Coffee Disease Risk Analysis: How Epidemiology Knowledge Could Help In Assessing and Preventing Disease Invasion. Proceedings of $22^{\text {nd }}$ International Conference on Coffee Science, pp. 1422-1423.

[22] Melke A, Ittana F (2015). Nutritional requirement and management of Arabica coffee (Coffea arabica L.) in Ethiopia: National and global perspectives. Am. J. Exp. Agric. 5: 400418.

[23] Huber L, Gillespie J (1992). Modelling Leaf Wetness in Relation to Plant Disease Epidemiology. Annu. Rev. Phyto. 30: 553-77. 